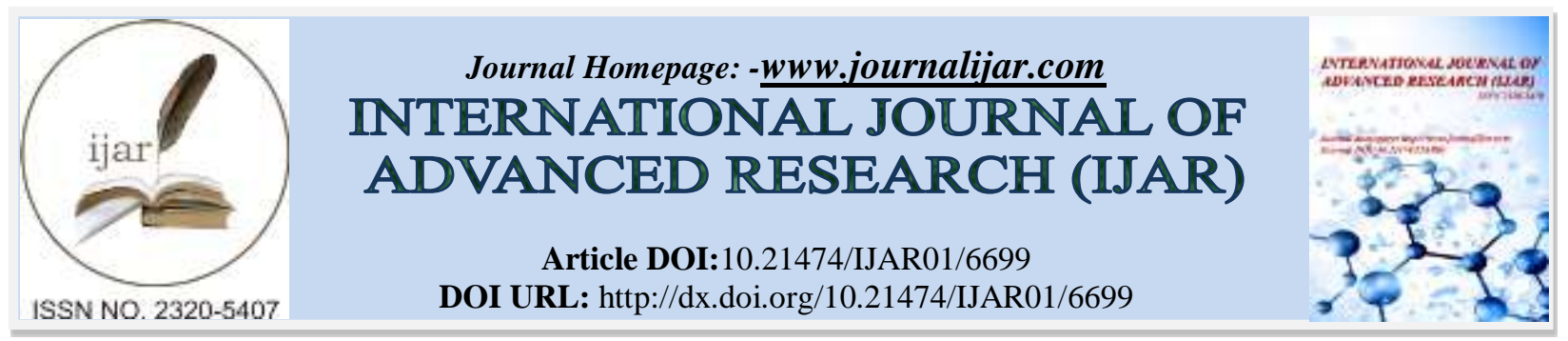

RESEARCH ARTICLE

\title{
EXHAUST GAS EMISSIONS ANALYSIS OF DUAL FUEL ON STATIONERY DIESEL ENGINE
}

\section{Fitri Dwirani ${ }^{1}$, Frebhika Sri Puji Pangesti ${ }^{1}$ and Agung Sudrajad ${ }^{2}$.}

1. Universitas Banten Jaya, Faculty of Engineering, Dept. of Environmental Engineering, Warung Pojok, Serang, Banten - Indonesia.

2. Universitas Sultan Ageng Tirtayasa, Faculty of Engineering, Dept. of Mechanical Engineering, Cilegon, Banten - Indonesia.

\section{Manuscript Info}

Manuscript History

Received: 08 January 2018

Final Accepted: 10 February 2018

Published: March 2018

Keywords:-

Exhaust emissions, dual fuel, biogas, diesel engine.

\section{Abstract}

The analysis of exhaust gas from diesel engine using dual fuel was examined. The objective of this research is to measure the exhaust gas emissions from single cylinder diesel engine using dual fuel (diesel fuel and biogas). The experimental study was conducted on single cylinder diesel engine with variable of engine speed and volume of biogas intake into combustion chamber. The results show that $\mathrm{CO}$ emission were $2.99 \%$ volume higher than the conventional fuel. The $\mathrm{CO}_{2}$ emissions were decrease by $9.53 \%$ when using dual fuel. The $\mathrm{HC}$ emissions of dual fuel were high in the case of high in-cylinder temperature at the high load condition Moreover, the opacity of exhaust emission was decrease by $14.3 \%$ at 50 psi load, but slightly increase at 100 psi.

Copy Right, IJAR, 2018,. All rights reserved.

\section{Introduction:-}

Recently the alternative fuel is a substitution of conventional fuel. The alternative fuel also already used in domestic activity. Biogas is a gas product material from microorganism activity. Biogas is one of alternative fuel as environmental friendly. The objective of this research is to know the exhaust gas emissions of single cylinder diesel engine using dual fuel (diesel fuel and biogas). Biogas is characterized based on its chemical composition and the physical characteristics which result from it. It is primarily a mixture of methane $\left(\mathrm{CH}_{4}, 50-70 \%\right)$ and inert carbonic gas $\left(\mathrm{CO}_{2}, 30-40 \%\right)$ (Kadarwati, 2003). Biogas is gases resulting from specific treatment processes, starting from various organic waste - industries, animal or domestic origin waste etc. The experimental material of biogas in this research is from Lembang, West Java- Indonesia. Table 1 shows the characteristics of biogas research material. 
Table 1:- Biogas Specification

\begin{tabular}{|l|l|}
\hline Name of Chemical & \multicolumn{1}{|c|}{ Percentage } \\
\hline $\mathrm{CH}_{4}$ & $10.76 \%$ \\
\hline $\mathrm{CO}_{2}$ & $13.63 \%$ \\
\hline $\mathrm{O}_{2}$ & $8.33 \%$ \\
\hline $\mathrm{H}_{2} \mathrm{~S}$ & $0 \mathrm{ppm}$ \\
\hline Energy & $154 \mathrm{Btu}$ \\
\hline
\end{tabular}

Emissions is an important major species in combustion because of its contribution to air pollution. In the combustion of fuels that contain of nitrogen, oxygen, carbon and sulfur are formed by chemical mechanisms or routes that involve some gases from the air (Sudrajad, 2011). The thermal mechanism dominates in high-temperature combustion over a fairly wide range of equivalence ratios, while the composition mechanism is particularly important in rich combustion. It appears that some gases play an important role in the production of emissions in very lean, low-temperature combustion processes.

\section{Research Methodology:-}

In experiments, we evaluated the effects of the variation of biogas, the fuel delivery advance angle of the auxiliary fuel pump and the scavenging pressure on four poisonous emissions: hydrocarbon (HC), carbon monoxide (CO) and carbon dioxide $\left(\mathrm{CO}_{2}\right)$. The direct cylinder diesel engine was examined in the experiment. Table 2 show the specification of engine.

Table 2:- Diesel Engine Specification

\begin{tabular}{|l|c|}
\hline \multicolumn{1}{|c|}{ Items } \\
\hline Stroke & 4 stroke \\
\hline Cooling system & Water Cooling \\
\hline Cylinder & Single Cylinder \\
\hline Cylinder Dimension & $75 \times 80(\mathrm{~mm})$ \\
\hline Combustion System & Indirect \\
\hline Maximum Power & $7 \mathrm{hp} / 2600 \mathrm{rpm}$ \\
\hline NCR & $6 \mathrm{hp} / 2600 \mathrm{rpm}$ \\
\hline Starting System & Motor DC \\
\hline Engine Dimension $(\mathrm{P} \times \mathrm{L} \times \mathrm{T})$ & $589 \times 341 \times 463(\mathrm{~mm})$ \\
\hline Weight & $65 \mathrm{~kg}$ \\
\hline
\end{tabular}

The engine speed parameter is set on $2000 \mathrm{rpm}$ and the load of engine set at $50 \mathrm{psi}$ and $100 \mathrm{psi}$. The engine is run at desired engine speed at the beginning of each setup. Then, the load is exerted to the engine after stable operating condition is achieved. The data is taken after the load exerted where the speed measurement remain stable for at least five minutes. The engine is run using conventional diesel fuel at the beginning to obtain base data for comparison. For test dual fuel data measurement, the engine is run with diesel fuel for beginning. After ten minutes running on diesel fuel, the valve supplying the diesel fuel to the engine is controlled, the valve for supplying biogas into the engine is opened. All the testing procedures are repeated for three times for the same condition. 


\section{Results and Discussions:-}

Figure 1 shows the effect of the Biogas inlet flow on emissions. It is shown that $\mathrm{CO}$ were recorded to increase with increased biogas input. However, the $\mathrm{CO}$ emissions on 100 psi engine load higher than 50 psi. This tendency was more evident as increased the load mean increase the burned of fuel quantity. The $\mathrm{CO}$ emissions on this experiment, based on the Emissions Indonesian Regulation is still in standard. A significant reduction in CO emission was shown between $50 \mathrm{psi}$ and $100 \mathrm{psi}$ at $2000 \mathrm{rpm}$ engine speeds. This reduction may be explained by the extra fuel oxygen. At high load, sufficient oxygen is not available in the engine cylinder. Therefore, the beneficial effects of dual fuel as an oxygenated fuel are seen at full loads. $\mathrm{CO}$ compete for the available oxygen in the rich combustion regime at full engine load. At partial loads, there is no appreciable difference between the fuels due to the dominant premixed lean combustion with excess oxygen and there is more stable $\mathrm{CO}$ variation.

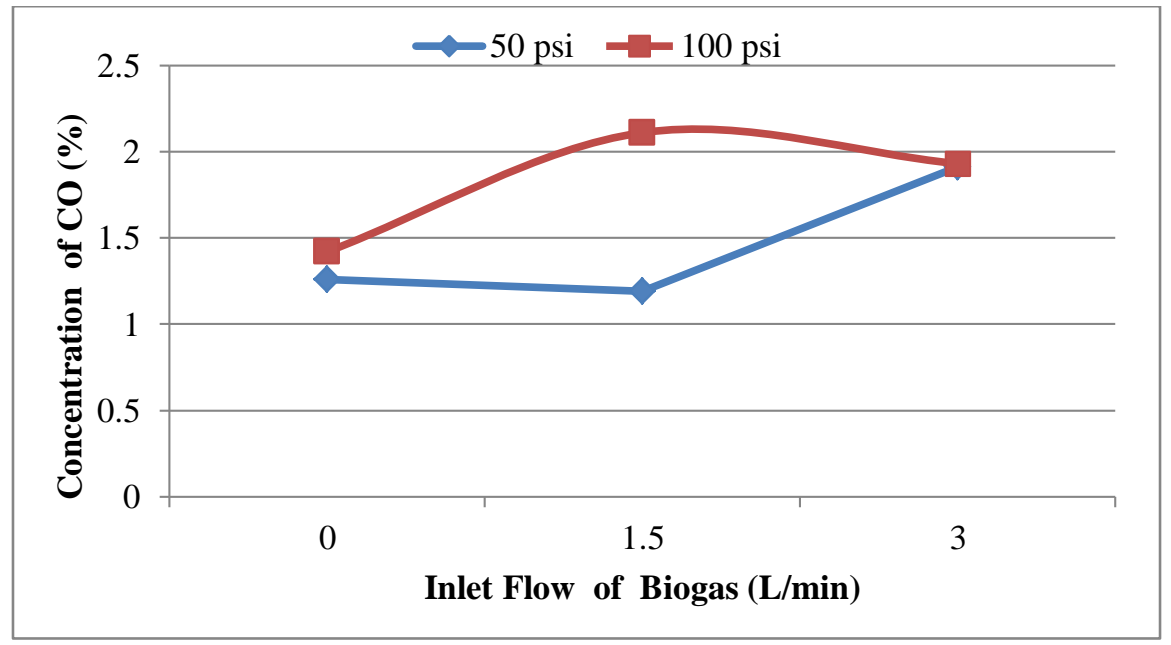

Figure 1:- CO emissions at $2000 \mathrm{rpm}$ engine speed

The $\mathrm{CO}_{2}$ emission shown in figure 2. It shows that the concentration emission of $\mathrm{CO}_{2}$ decreases by increased of biogas input. Concentration of $\mathrm{CO}_{2}$ shows the direct process of combustion in engine. The Air Fuel Ratio (AFR) around $12 \%-15 \%$, this affect to the rich combustion.

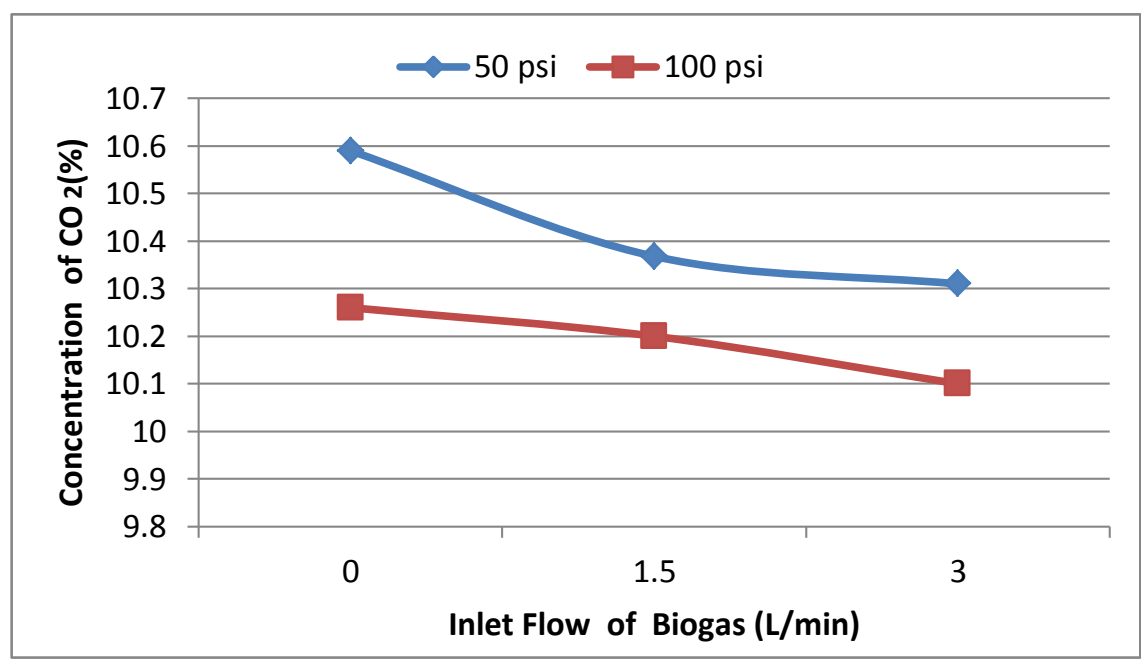

Figure 2:- $\mathrm{CO}_{2}$ emissions at $2000 \mathrm{rpm}$ engine speed 


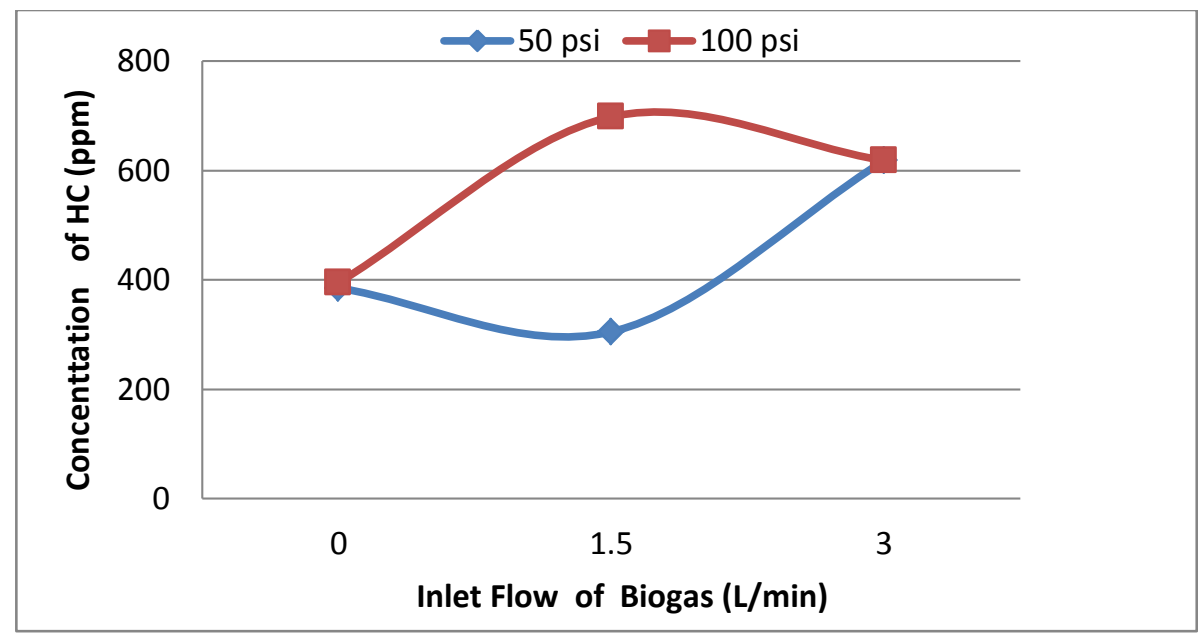

Figure 3:- HC emissions at 2000 rpm engine speed

The HC emissions of dual fuel were high in the case of high in-cylinder temperature at the high load condition as shown in figure 3 . The Indonesian regulation of exhaust emissions is $250 \mathrm{ppm}$ in maximum, however the data shows $\mathrm{HC}$ emissions by dual fuel in this experiment were more than $250 \mathrm{ppm}$ in both engine load.

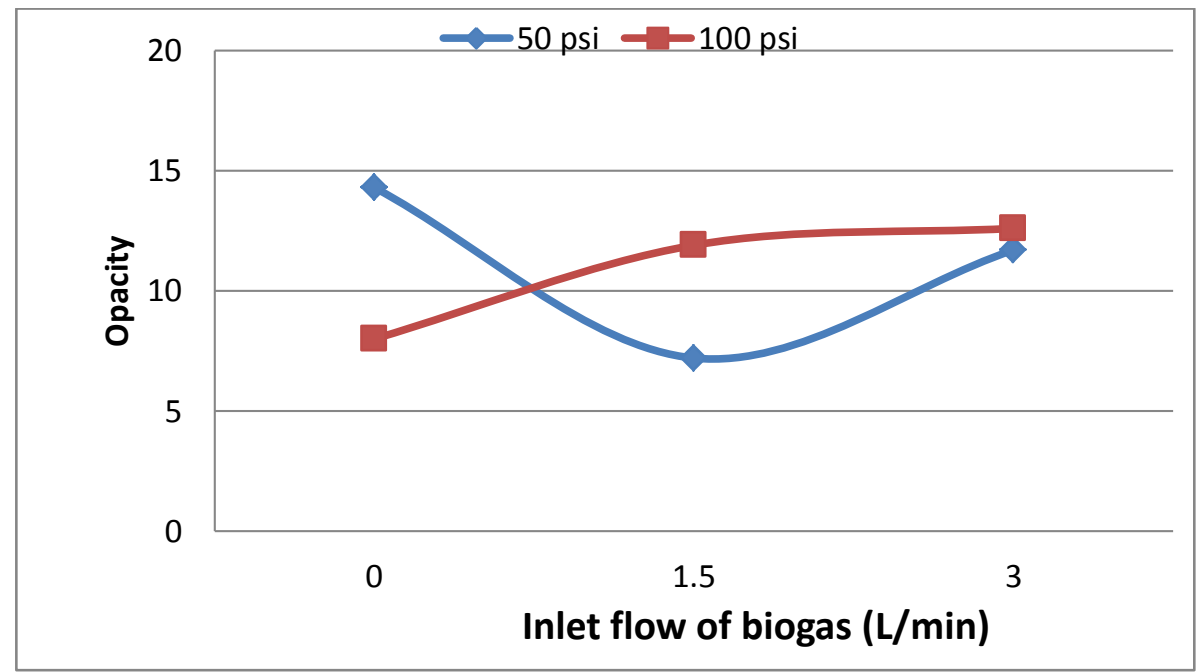

Figure 4:- Opacity at 2000 rpm engine speed

The smoke of the engine fueled with dual fuel increased with increasing biogas percentage in dual fuel at 50 psi engine load. This could be explained by the biogas fuel oxygenating the smoke during the combustion process. The maximum torque speed of the engine, $2000 \mathrm{rpm}$, was also maintained with the dual fuel. The addition of biogas to the diesel fuel initially increased the torque and the power due to the possible reasons of high temperature of combustion.

\section{Conclusions:-}

In this paper, biogas produced from Lembang West Java Indonesia has been tested in a diesel engine. The experimental results are described that the $\mathrm{CO}$ were recorded to increase with increased biogas input. However, the $\mathrm{CO}$ emissions on $100 \mathrm{psi}$ engine load was higher than $50 \mathrm{psi}$. This tendency was more evident as increased the load mean increase the burned of fuel quantity. The HC emissions of dual fuel were high in the case of high in-cylinder temperature at the high load condition. Biogas as alternative fuel can be partially used in diesel engines without any engine modification. 


\section{References:-}

1. Himsar, Ambarita. (2017). Performance And Emission Characteristics Of Small Diesel Engine Run In Dual Fuel (Diesel - Biogas) Mode. Journal of Case Studies in Thermal Engineering 10 pp 179-191.

2. Kadarwati, S. (2003). Study of Biogas from Organic Compound with Lab Scale, Journal of P3TEK, Vol 2 No.1, pp. 3 - 10 .

3. Ministry of Environmental. (2009). Regulation No 5/2009 The Standard of Exhaust Emissions from Vehicle. Jakarta

4. N. Usta. (2005). An experimental study on performance and exhaust emissions of a diesel engine fuelled with tobacco seed oil methyl ester. Energy Conversion and Management 46 (2005) 2373-2386

5. Sudrajad, Agung, Fujita Hirotsugu, and Ismail Ali. (2011). Experimental study of exhaust emissions of W/O emulsion fuel in DI single cylinder diesel engine. Modern applied science 5.5 (2011): 73.

6. Tanuch Alib, Ipick Setiawan, Agung Sudrajat. (2015). Torque Analysis of Single Cylinder Diesel Engine. Faculty of Engineering. Universitas Sultan Ageng Tirtayasa: Cilegon. 